EESTI NSV TEADUSTE AKADEEMIA TOIMETISED 1955. IV kd., nr. 2 ИЗВЕСТИЯ АКАДЕМИИ НАУК ЭСТОНСКОИ ССР 1955. Том IV, № 2

\title{
К ВОПРОСУ О РОЛИ CLOSTRIDIUM PASTEURIANUM В КОРНЕВОМ ПИТАНИИ РАСТЕНИИ
}

\author{
Р. С. ГОЛОВАЧЕВА
}

Clostridium Pasteurianum является одним из наиболее распространенных в природе микроорганизмов, способных усваивать молекулярный азот. Виноградским $\left({ }^{3}\right)$, Бредеманом, Омелянским и Солунековой $\left({ }^{7}\right)$, Рыбалкиной $\left({ }^{8}\right)$ и другими установлено почти повсеместное распространение $C l$. Pasteurianum в различных почвах. Наибольшее содержание его в почве достигает порядка сотен тысяч и даже нескольких миллионов на 1 г почвы. В Эстонской ССР, по нашим наблюдениям, лишь в некоторых почвах численность $\mathrm{Cl}$. Pasteurianum в летне-осенний период не превышает сотни на 1 г почвы, в болышинстве же исследованных почв она выше тысячи и достигает часто нескольких тысяч, а подчас и миллионов.

Cl. Pasteurianum, несомненно, заслуживает большего внимания к себе со стороны микробиологов, что с полной определенностью подчеркивает также Федоров. «Если считаться только с широтой распространения этой бактерии в почве, - пишет он, - то ее следует признать за одного из важнейших фиксаторов азота». И далее: «Этот микроорганизм несправедливо забыт всеми» $\left({ }^{9}\right)$.

До сих пор основное внимание почвенных микробиологов было направлено на изучение аэробного фиксатора азота - азотобактера, значение же $C l$. Pasteurianum в азотном балансе почвы, его роль в корневом Питании растений оставались мало изученными. Причиной отсутствия должного интереса к этому организму, повидимому, является утвердившееся в литературе представление о том, что эффективность азотфиксации $\mathrm{Cl}$. Pasteurianum невелика, поскольку в процессе брожения он освобождает в 10 раз меньше энергии, чем азотобактер в процессе окисления.

Исследования последних лет, однако, опровергают это представление.

Федоров $\left({ }^{9}\right)$, ссылаясь на собственные данные и данные различных исследователей, по которым продуктивность фиксации азота атмосферы Cl. Pasteurianum колебалась от 1,5 до 7 мг на 1 г сброженного сахара, объясняет эти колебания различными условиями и тем, «что брожение сахара и ассимиляция атмосферного азота не так тесно связаны между собой, как можно было бы думать.»

Розенблюм и Вильсон $\left({ }^{2,11}\right)$ в своих опытах, детально изучив физиологию $\mathrm{Cl}$. Pasteurianum, достигли повышения фиксации азота этим организмом до $10-12$ мг на 1 г углевода за 48-72 часа. Такие показатели сходны с теми, которые получены в опытах с азотобактером.

Относительно влияния $\mathrm{Cl}$. Pasteurianum на высшее растение в литера- 
туре имеется мало данных. Большая часть имеющихся работ свидетельствует о положительном влиянии этого организма на рост растений и урожайность.

Так, Трюффо и Бессонов $\left({ }^{4}\right)$ в асептических условиях песчаной кульгуры выращивали кукурузу, которая получала азот только от $\mathrm{Cl}$. Pasteurianum, развивавшегося в ее ризосфере за счет корневых выделений.

В вегетационных опытах Березовой (') были получены прибавки урожая льна при применении Cl. Pasteurianum по фону NPK.

Возняковская $\left({ }^{4}\right)$ в вегетационных опытах испытала действие $\mathrm{Cl}$. Pasteurianum на просо.и кукурузу. Это действие тоже оказалось положительным. При совместном применении Cl. Pasteurianum и азотобактера эффективность их действия на урожайность растений была выше, чем при раздельном испытании этих бактерий.

Указанные вегетационные, а также лабораторные опыты Возняковской по выяснению влияния $\mathrm{Cl}$. Pasteurianum на размножение азотобактера при совместном их культивировании и на общую способность фиксации азота являются продолжением исследования симбиотических взаимоотношений между $\mathrm{Cl}$. Pasteurianum и азотобактером, наличие которых было установлено еще классическими опытами Омелянского $\left({ }^{7}\right)$, а затем изучалось Шкляр $\left({ }^{10}\right)$.

Возняковская и Рыжкова $\left(^{5}\right)$ при исследовании ризосферной микрофлоры озимой пшеницы в полевых опытах по изучению действия смесей из органического удобрения, суперфосфата и извести установили, что внесение удобрений, как раздельно, так и особенно в смеси, приводит к резкому увеличению численности бактерий. Содержание $\mathrm{Cl}$. Pasteurianum при этом в ризосфере пшеницы в вариантах с удобрением в течение всего вегетационного периода было в $100-500$ раз выше, чем в контроле. Самым высоким оно было в варианте со смесью из всех трех испытываемых удобрений. Поскольку азотобактер ни в одном случае обнаружен не был, авторы делают вывод; что обеспечение растений азотом обусловливалось анаэробной фиксацией азота.

Целью проведения данной работы являлось выяснение влияния Cl. Pasteurianum на прорастание семян, рост и урожайность зерновых культур. Испытание эффективности $\mathrm{Cl}$. Pasteurianum проводилось нами в сравнении с эффективностью азотобактера и фосфоробактерий. Наряду с этим в одном из опытов для выяснения роли $C l$. Pasteurianum как фактора, повышающего эффективность бактеризации семян азотобактером и фосфоробактериями, нами испытывались различные сочетания всех трех видов бактерий.

\section{Опыты по выяснению влияния азотфиксаторов и фосфоробактерий на} прорастание семян и рост проростков

Для выяснения вопроса о влиянии Cl. Pasteurianum на прорастание семян был поставлен лабораторный опыт с семенами овса и пшеницы. В этом опыте с целью сравнения испытывались также азотобактер и фосфоробактерии. Методика постановки опыта была следующая: одинаковые по размеру семена, после стерилизации их раствором перманганата калия и последовавшей за этим тщательной промывки стерильной водой, были помещены до наклевывания в стерильные чашки Петри между двумя влажными кружками фильтровальной бумаги. Через двое суток одинаково наклюнувшиеся семена инокулировались чистыми молодыми культурами бактерий. Для инокуляции использовались штаммы клостридия и азотобактера, выделенные из дерново-карбонатных почв Эстонской ССР, и фосфоробактерии, отвитые из фабричного препарата жидкого фосфоро- 
бактерина. Сразу же после инокуляции семена по пять штук были высеяны в простерилизованные в автоклаве чашки Петри с дерново-карбонатной почвой, взятой с огородного участка филиала Куузику Института растениеводства АН ЭССР. Повторность опыта в серии с овсом была трехкратная, в серии с пшеницей - четырехкратная. Опыт проводился при комнатной температуре, в течение пяти суток, считая с момента инокуляции.

Необходимо отметить тот факт, что Cl. Pasteurianum, внесенный в почву вместе с семенами, интенсивно в ней развивался, о чем можно было судить по резкому запаху масляной кислоты, издаваемому почвой.

По окончании опыта была измерена длина корешков и ростков растений (таблица 1).

Таблица 1

Влияние бактерий на прорастание семян и рост проростков овса и пшеницы

\begin{tabular}{|c|c|c|c|c|c|c|c|}
\hline \multirow{3}{*}{ Вариант } & \multirow{3}{*}{$\begin{array}{l}\text { Pac- } \\
\text { те- } \\
\text { ние }\end{array}$} & \multicolumn{3}{|c|}{ Корешки } & \multicolumn{3}{|c|}{ Ростки } \\
\hline & & \multirow{2}{*}{$\begin{array}{c}\text { Средняя } \\
\text { длина } \\
\text { в см }\end{array}$} & \multicolumn{2}{|c|}{ Прнбавка } & \multirow{2}{*}{$\begin{array}{l}\text { Средняя } \\
\text { длина } \\
\text { в см }\end{array}$} & \multicolumn{2}{|c|}{ Прибавка } \\
\hline & & & B $\mathrm{CM}$. & в $\%$ & & в CM & B $\%$ \\
\hline $\begin{array}{l}\text { Контроль } \\
\text { Cl. Pasteurianum } \\
\text { Азотобактер } \\
\text { Фосфоробактерии }\end{array}$ & 岕 & $\begin{array}{l}4,81 \\
5,44 \\
5,20 \\
5,89\end{array}$ & $\begin{array}{l}\overline{-63} \\
0,39 \\
1,08\end{array}$ & $\begin{array}{r}\overline{13,1} \\
8,1 \\
22,2\end{array}$ & $\begin{array}{l}3,01 \\
3,97 \\
3,25 \\
3,78\end{array}$ & $\begin{array}{l}0, \overline{96} \\
0,24 \\
0,77\end{array}$ & $\begin{array}{r}3 \overline{1}, 9 \\
8,0 \\
25,0\end{array}$ \\
\hline $\begin{array}{l}\text { Контроль } \\
\text { Cl. Pasteurianum } \\
\text { Азотобактер } \\
\text { Фосфоробактерии }\end{array}$ & 墨 & $\begin{array}{l}4,77 \\
6,57 \\
6,22 \\
5,90\end{array}$ & $\begin{array}{l}\overline{1,80} \\
1,45 \\
1,13\end{array}$ & $\begin{array}{l}3 \overline{7}, 7 \\
30,2 \\
23,7\end{array}$ & $\begin{array}{l}3,55 \\
4,50 \\
4,25 \\
4,60\end{array}$ & $\begin{array}{l}\overline{-}, \overline{95} \\
0,70 \\
1,05\end{array}$ & $\begin{array}{l}\overline{26,8} \\
19,7 \\
29,6\end{array}$ \\
\hline
\end{tabular}

Как видно из таблицы, все испытываемые бактерии стимулировали прорастание семян и рост проростков, при этом более сильно их воздействие сказалось на пшенице.

Красильников $\left({ }^{6}\right)$ называет бактерий, которые ускоряют прорастание семян и рост проростков и повышают урожай, активаторами. Микробыактиваторы воздействуют на растения продуктами своей жизнедеятельности, биотическими веществами.

Биотические вещества образуются многими микроорганизмами. Одним из наиболее активных их продуцентов является азотобактер.

На основании наших опытов можно заключить, что $\mathrm{Cl}$. Pasteurianum также образует какие-то вещества, благодаря которым он, подобно бактериям-активаторам, стимулирует прорастание семян.

На таком же основании подобное заключение можно сделать в отношении фосфоробактерий, так как их влияние на прорастание семян в нашем опыте проявилось не менее ярко.

\section{Опыты по выяснению влияния Clostridium Pasteurianum на рост овса и его урожайность}

Для выяснения влияния $C l$. Pasteurianum на рост и урожайность зерновых культур были проведены вегетационные опыты с овсом и полевой опыт с ячменем.

Влияние $\mathrm{Cl}$. Pasteurianum на рост овса испытывалось в трех последовательно проведенных вегетационных опытах. Опыты эти разведыва- 
тельного порядка, поэтому были поставлены.без повторностей. Методика их постановки заключалась в следующем: инокулированные культурой клостридия семена овса высевались по 15 штук в простерилизованные в автоклаве вазоны с дерново-карбонатной почвой (по 1,6 кг на сосуд), к которой в качестве удобрения было добавлено $10 \%$ хорошо разложившегося низинного торфа, $0,1 \%$ сланцевой золы, $0,2 \%$ суперфосфата и $0,2 \%$ калийной соли. Контролями служили вазоны, засеянные неинокулированными семенами. Продолжительность каждого опыта - один месяц.

После окончания опытов определялся вес зеленой массы растений по вариантам и делались микробиологические анализы ризосферной почвы.

Данные этих опытов приведены в таблице 2.

Таблица 2

Влияние инокуляции семян культурой Clostridium Pasteuritanum на рост овса

\begin{tabular}{|c|c|c|c|c|c|}
\hline \multirow{2}{*}{$\begin{array}{c}\text { № } \\
\text { опыта }\end{array}$} & \multirow{2}{*}{ Варианты опытов } & \multirow{2}{*}{$\begin{array}{l}\text { Количество } \\
\text { клеток Cl. } \\
\text { Pasteurianum } \\
\text { в } 1 \text { г ризо- } \\
\text { сферной почвы }\end{array}$} & \multirow{2}{*}{$\mathrm{pH}$} & \multicolumn{2}{|c|}{ Вес одного растения } \\
\hline & & & & B $\mathrm{r}$ & B $\%$ \\
\hline I & $\begin{array}{l}\text { Контроль } \\
\text { Cl. Pasteurianum накопитель- } \\
\text { ная культура, перед иноку- } \\
\text { ляцией прогретая в течение } \\
1,5 \text { мин. при } 100^{\circ} \mathrm{C}\end{array}$ & 100000 & - & 1,49 & 100,0 \\
\hline II & $\begin{array}{l}\text { Контроль } \\
\text { Cl. Pasteurianum (прнменен- } \\
\text { ный так же, как в опыте I) * }\end{array}$ & $\begin{array}{c}0 \\
\text { Не менее } \\
1000000 \\
\text { Не менее } \\
1000000\end{array}$ & $\begin{array}{l}7,9 \\
7,9 \\
7,9\end{array}$ & $\begin{array}{l}0,61 \\
0,95\end{array}$ & $\begin{array}{l}100,0 \\
155,7\end{array}$ \\
\hline III & $\begin{array}{l}\text { Контроль } \\
\text { Cl. Pasteurianum (чистая куль- } \\
\text { тура) }\end{array}$ & $\begin{array}{c}0 \\
10000\end{array}$ & - & 0,187 & $\begin{array}{l}100,0 \\
125,6\end{array}$ \\
\hline
\end{tabular}

* В двукратной повторности.

Резкое различие по урожайности в опытах объясняется неодинаковой их освещенностью, так как поставлены они были в разное время года.

Приведенные данные свидетельствуют о положительном действии Cl. Pasteurianum на рост овса. Во всех трех опытах вес зеленой массы в вариантах с клостридием был значительно больше, чем в контрольных вариантах. Cl. Pasteurianum, внесенный в почву вместе с семенами, интенсивно развивался в ризосфере растений. Как видно из таблицы 2, максимальным прибавкам урожая соответствовало и наибольшее содержание фиксатора азота в почве данных вариантов. Это говорит о наличии связи между ростом овса и развитием $C l$. Pasteurianum в его ризосфере.

Целью следующего вегетационного опыта было выяснение действия Cl. Pasteurianum на урожайность овса в сравнении с азотобактером и фосфоробактериями на различных типах почв. В данном опыте также испытывалась эффективность применения различных сочетаний этих трех бактерий. 
Опыт состоял из следующих трех серий:

I серия. На дерново-карбонатной почве с добавлением небольших количеств компоста, песка и верхового торфа, $0,25 \%$ суперфосфата и $0,13 \%$ калийной соли $(\mathrm{pH}=7,6)$.

II серия. На дерново-подзолистой почве с добавлением небольших количеств песка и верхового торфа, $0,2 \%$ суперфосфата, $0,1 \%$ калийной соли и $2,0 \%$ сланцевой золы $(\mathrm{pH}=7,6)$.

III серия. На почве такого же состава, что и для II серии, но без сланцевой золы ( $\mathrm{pH}=5,8)$.

Для опыта использовались вазоны, вмещавшие по 3,5 кг почвы. Вазоны с почвой были простерилизованы в автоклаве при давлении пара в 1 атм в течение 1 часа. Посев производился наклюнувшимися семенами в лунки, сделанные в почве. Семена в лунках инокулировались смачиванием их суспензиями бактерий. Когда появились всходы, в каждом вазоне было оставлено по 20 растений. Повторность опыта трехкратная.

Схема опыта и данные представлены в таблице 3.

Из приведенных данных прежде всего видно, что серии резко различались по общей урожайности. Наиболее высокие урожаи были получены на дерново-карбонатной почве с компостами, самые низкие - на кислой подзолистой почве. Применение сланцевой золы почти в два раза повысило плодородие подзолистой почвы.

Эффективность бактеризации проявилась в опытах неодинаково. По всем вариантам наибольший относительный эффект бактеризация имела на самой неплодородной кислой почве, значительно ниже был эффект в серии с карбонатной почвой и совсем незначительный на подзолистой почве со сланцевой золой.

Из испытываемых микроорганизмов нанболее эффективными во всех трех сериях, несмотря на высокие дозы фосфорного удобрения, оказались фосфоробактерии. На карбонатной почве они обусловливали повышение урожая зерна на $19,8 \%$, на подзолистой почве с известкованием - на $9,3 \%$, на кислой подзолистой - на $25,8 \%$.

В вариантах с азотобактером на карбонатной почве прибавка урожая зерна была $13,6 \%$, на подзолистой с известкованием - 4,9\% и на подзолистой кислой $-25,2 \%$.

Однако здесь необходимо оговориться. Из представленных в таблице данных микробиологических анализов видно, что $\mathrm{Cl}$. Pasteurianum развивался не только в тех вариантах, в которые он был внесен, но и во всех других, в том числе и в контрольных, что явилось следствием проведения опыта в нестерильных условиях.

Так как варианты с фосфоробактериями мало отличались по количеству Cl. Pasteurianum от контрольных вариантов, следует, полагать, что прибавки урожая в них обусловлены в основном развитием фосфоробактерий.

Что касается вариантов с азотобактером, то на карбонатной почве и в серии с известкованием его эффективность (хотя в последнем случае она и незначительна) не вызывает сомнений, поскольку азотобактер в обоих случаях развивался хорошо, а Cl. Pasteurianum было не больше, чем в контрольных вазонах.

В сосудах же с азотобактером на кислой почве при совсем незначительном содержании азотобактера количество $\mathrm{Cl}$. Pasteurianum было велико. Следовательно, высокая прибавка урожая в данном варианте обусловлена скорее совместным влиянием на растения обоих азотфиксаторов, чем деятельностью только азотобактера.

Данные таблицы 3 показывают, что внесение $\mathrm{Cl}$. Pasteurianum оказывало положительное действие на урожайность овса. На карбонатной 
Таблица 3

Сравнение действия бактерий на урожайность овса в различных почвенных условиях *

\begin{tabular}{|c|c|c|c|c|c|c|c|c|c|}
\hline \multirow{3}{*}{ 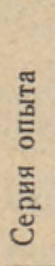 } & \multirow{3}{*}{ В а ри ан т } & \multicolumn{4}{|c|}{$\begin{array}{c}\text { Количество микроорганизмов } \\
\text { в } 1 \text { г почвы }\end{array}$} & \multicolumn{2}{|c|}{$\begin{array}{l}\text { Урожай } \\
\text { зерна }\end{array}$} & \multicolumn{2}{|c|}{$\begin{array}{l}\text { Урожай } \\
\text { соломы }\end{array}$} \\
\hline & & \multicolumn{2}{|c|}{ 27. VI } & \multicolumn{2}{|c|}{ 6. VIII } & \multirow[b]{2}{*}{ B $\mathrm{r}$} & \multirow[b]{2}{*}{ в $\%$} & \multirow[b]{2}{*}{ B F } & \multirow[b]{2}{*}{ в $\%$} \\
\hline & & $\begin{array}{l}\text { Cl. Pas- } \\
\text { teuri- } \\
\text { anum }\end{array}$ & $\begin{array}{l}\text { Azoto- } \\
\text { bacter }\end{array}$ & $\begin{array}{l}\text { Cl. Pas- } \\
\text { teuri- } \\
\text { anum }\end{array}$ & $\begin{array}{l}\text { Azoto- } \\
\text { bacter }\end{array}$ & & & & \\
\hline \multirow{8}{*}{ 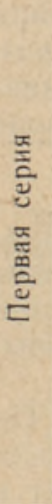 } & Контроль & 40000 & 0 & 600 & 0 & 18,35 & 100,0 & 21,39 & 100,0 \\
\hline & Cl. Pasteur. & 500000 & 0 & 2500 & 0 & 20,20 & 110,9 & 22,13 & 103,4 \\
\hline & Азотобактер & - & - & 600 & 3100 & 20,86 & 113,6 & 22,32 & 104,3 \\
\hline & Фосфоробактерии & 60000 & 0 & 100 & + & 21,99 & 119,8 & 22,62 & 105,7 \\
\hline & $\begin{array}{l}\text { Cl. Pasteur. }+ \text { азо- } \\
\text { тобактер }\end{array}$ & 400000 & 11100 & 25000 & 1500 & 20,82 & 113,4 & 22,56 & 105,5 \\
\hline & $\begin{array}{l}\text { Cl. Pasteur. + фос- } \\
\text { форобактерии }\end{array}$ & 600000 & 0 & - & - & 21,32 & 116,2 & 22,96 & 107,3 \\
\hline & $\begin{array}{l}\text { Азотобактер + } \\
\text { фосфоробакте- } \\
\text { рии }\end{array}$ & & - & - & - & 20,77 & 113,2 & 23,33 & 111,4 \\
\hline & $\begin{array}{l}\text { Cl. Pasteur. + азо- } \\
\text { тобактер + фос- } \\
\text { форобактерии }\end{array}$ & 60000 & 19000 & 6000 & 1400 & 20,39 & 111,1 & 22,34 & 104,1 \\
\hline \multirow{8}{*}{ 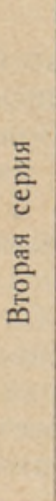 } & Контроль & 25 & 0 & 600 & 0 & 7,01 & 100,0 & 7,00 & 100,0 \\
\hline & Cl. Pasteur. & 250000 & 0 & 2500 & 0 & 7,44 & 106,1 & 7,23 & 104,1 \\
\hline & Азотобактер & - & - & 1300 & 10000 & 7,36 & 104,9 & 7,40 & 105,7 \\
\hline & Фосфоробактерии & - & & 1300 & 0 & 7,66 & 109,3 & 7,17 & 102,4 \\
\hline & $\begin{array}{l}\text { Cl. Pasteur. }+ \text { азо- } \\
\text { тобактер }\end{array}$ & 2500 & 13500 & 25000 & 3740 & 7,37 & 105,1 & 7,54 & 107,7 \\
\hline & $\begin{array}{l}\text { Cl. Pasteur. + фос- } \\
\text { форобактерии }\end{array}$ & 25000 & 0 & 6000 & 0 & 7,58 & 108,0 & 7,42 & 106,0 \\
\hline & $\begin{array}{l}\text { Азотобактер }+ \\
\text { фосфоробакте- } \\
\text { рии }\end{array}$ & - & - & - & 6500 & 7,40 & 105,5 & 7,18 & 102,5 \\
\hline & $\begin{array}{l}\text { Cl. Pasteur. + азо- } \\
\text { тобактер + фос- } \\
\text { форобактерии }\end{array}$ & - & & 25000 & 12000 & 7,92 & 111,9 & 8,00 & 114,3 \\
\hline \multirow{8}{*}{ 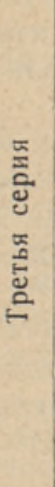 } & Контроль & 6000 & 0 & 250000 & 0 & 3,44 & $1 \cup 0,0$ & 4,43 & 100,0 \\
\hline & Cl. Pasteur. & 60000 & 0 & 60000 & 0 & 3,99 & 115,9 & 4,48 & 101,5 \\
\hline & Азотобактер & - & - & 60000 & 40 & 4,31 & 125,2 & 4,52 & 102,0 \\
\hline & Фосфоробактерии & - & - & 250000 & 0 & 4,33 & 125,8 & 4,57 & 103,1 \\
\hline & $\begin{array}{l}\text { Cl. Pasteur. + азо- } \\
\text { тобактер }\end{array}$ & 250000 & 80 & - & 0 & 3,96 & 115,1 & 4,19 & 94,6 \\
\hline & $\begin{array}{l}\text { Cl. Pasteur. + фос- } \\
\text { форобактерии }\end{array}$ & 250000 & 0 & 2500000 & 0 & 5,19 & 150,8 & 5,27 & 118,9 \\
\hline & $\begin{array}{l}\text { Азотобактер }+ \\
\text { фосфоробакте- } \\
\text { рии }\end{array}$ & 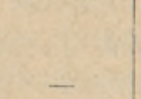 & - & 250000 & 20 & & 125,2 & & \\
\hline & $\begin{array}{l}\text { Cl. Pasteur. + азо- } \\
\text { тобактер + фос- } \\
\text { форобактерии }\end{array}$ & - & - & 250000 & 0 & 4,26 & 123,8 & 4,58 & 103,3 \\
\hline
\end{tabular}

* Опыт поставлен 25 мая 1954 г. 
почве прибавка урожая зерна составила $10,9 \%$, на подзолистой со сланцевой золой - $6,1 \%$ и на кислой - $15,9 \%$.

Применение различных сочетаний Cl. Pasteurianum, азотобактера и фосфоробактерий не дало ожидаемого эффекта. Остается неясным и отсутствие эффекта в вариантах с совместным применением Cl. Pasteurianum и азотобактера.

Из результатов опыта обращает на себя внимание высокая эффективность сочетания $\mathrm{Cl}$. Pasteurianum и фосфоробактерий на кислой почве. В данном случае прибавка урожая достигла $50,8 \%$. Содержание $\mathrm{Cl}$. Pasteurianum в ризосферной почве этого варианта было тоже максимальным - около 2,5 млн. на 1 г почвы. Описываемый факт не является случайным, подобное явление наблюдалось нами и раньше. Очевидно, между Cl. Pasteurianum и бактериями, минерализующими органофосфаты, существуют симбиотические взаимоотношения, что заслуживает детального изучения.

Полевой опыт с ячменем был заложен в филиале Куузику Института растениеводства АН ЭССР в 1952 году на дерново-карбонатной почве по фону фосфорного и калийного удобрений. В этом опыте сравнивалось влияние на урожайность ячменя обонх азотфиксаторов - Cl. Pasteurianum и азотобактера. Семена инокулировались в день посева. Для инокуляции использовались накопительная жидкая культура $\mathrm{Cl}$. Pasteurianum и агаровый азотобактерин. Опытные делянки были площадью по $50 \mathrm{~m}^{2}$; повторность опыта - трехкратная. При появлении всходов половине всех делянок был дан азот в виде аммиачной селитры из расчета 50 кг на 1 га. Результаты опыта приведены в таблице 4.

Таблица 4

Влияние азотфиксаторов на урожайность ячменя

\begin{tabular}{|c|c|c|c|c|c|c|c|}
\hline \multirow{2}{*}{$\begin{array}{c}\text { Мине- } \\
\text { раль- } \\
\text { ный } \\
\text { фон }\end{array}$} & \multirow{2}{*}{ Вариант } & \multicolumn{2}{|c|}{ Урожай зерна } & \multirow{2}{*}{$\begin{array}{c}\text { Прибав- } \\
\text { ка уро- } \\
\text { жая } \\
\text { зерна } \\
\text { в ц/га }\end{array}$} & \multicolumn{2}{|c|}{ Урожай соломы } & \multirow{2}{*}{$\begin{array}{c}\text { Прибав- } \\
\text { ка уро- } \\
\text { жая со- } \\
\text { ломы } \\
\text { в ц/га }\end{array}$} \\
\hline & & В ц/га & в $\%$ & & в u/ra & в $\%$ & \\
\hline PK & $\begin{array}{l}\text { Контроль } \\
\text { Cl. Pasteurianum } \\
\text { Азотобактер }\end{array}$ & $\begin{array}{l}22,2 \\
24,7 \\
25,6\end{array}$ & $\begin{array}{l}100,0 \\
111,4 \\
115,3\end{array}$ & $\begin{array}{l}\overline{2,5} \\
3,4\end{array}$ & $\begin{array}{l}19,0 \\
19,8 \\
20,8\end{array}$ & $\begin{array}{l}100,0 \\
104,2 \\
109,5\end{array}$ & $\begin{array}{l}\overline{0,8} \\
1,8\end{array}$ \\
\hline NPK & $\begin{array}{l}\text { Контроль } \\
\text { Cl. Pasteurianum } \\
\text { Азотобактер }\end{array}$ & $\begin{array}{l}37,0 \\
39,7 \\
38,2\end{array}$ & $\begin{array}{l}100,0 \\
107,3 \\
103,2\end{array}$ & $\begin{array}{l}\overline{2,7} \\
1,2\end{array}$ & $\begin{array}{l}35,1 \\
38,2 \\
38,5\end{array}$ & $\begin{array}{l}100,0 \\
108,8 \\
109,7\end{array}$ & $\begin{array}{l}\overline{3,1} \\
3,4\end{array}$ \\
\hline
\end{tabular}

Представленные данные говорят о том, что $\mathrm{Cl}$. Pasteurianum по степени воздействия на урожай зерна ячменя на безазотном фоне лишь немного уступает азотобактеру. Менее эффективно его влияние на урожай соломы.

На азотном фоне, при резком поднятии общей урожайности, в вариантах с азотфиксаторами прибавки урожая зерна значительно снизились, а урожая соломы возросли.

\section{Выводы}

1. Бактеризация семян овса и пшеницы культурой $\mathrm{Cl}$. Pasteurianum оказывала положительное влияние на их прорастание. По степени воздействия на прорастание семян и рост проростков $C l$. Pasteurianum не уступал азотобактеру и фосфоробактериям. 
2. В проведенных вегетационных опытах $\mathrm{Cl}$. Pasteurianum, будучи внесенным в почву вместе с семенами зерновых культур, интенсивно развивался в ризосфере этих растений. Его содержание при этом достигало порядка 1 млн. на 1 г почвы.

3. При бактеризации семян овса $\mathrm{Cl}$. Pasteurianum в вегетационных опытах наблюдалось усиление роста растений и повышение урожайности. Наибольшим прибавкам зеленой массы растений соответствовало и максимальное содержание $\mathrm{Cl}$. Pasteurianum в ризосферной почве.

4. В полевом опыте с ячменем прибавка урожая в варианте с Cl. Pasteurianum была лишь немного меньше, чем в варианте с азотобактером.

5. По данным проведенных нами вегетационных опытов, очень эффективным в отношении 'воздействия на урожайность овса является совместное применение $\mathrm{Cl}$. Pasteurianum и фосфоробактерий, на основании чего можно предположить о существовании симбиотических взаимоотношений между этими микроорганизмами, что подлежит дальнейшему изучению.

6. Результатами проведенных нами опытов подтверждаются данные других исследователей, свидетельствующие о положительном влиянии $\mathrm{Cl}$. Pasteurianum на высшее растение. Вопросы о связи между $\mathrm{Cl}$. Pasteurianum и высшими растениями и о роли анаэробного фиксатора азота в корневом питании растений заслуживают дальнейшего изучения.

Ннститут растениеводства

Академии наук Эстонской ССР
Поступила в редакцию 15 XII 1954

\section{ЛИТЕРАТУРА}

1. Е. Бе р ез о в а, О роли Amylobacter в развитии льна, «Микробиология», т. IX, вып. $9-10,1940$.

2. К. В ер км ан, П. В и льсон, Физиология бактерий, ИЛ, М., 1954.

3. С. Н. В и ног р а д ски й, Об усвоении свободного азота атмосферы микробами, Архив биологических наук, 3, 293, 1895.

4. Ю. М. Возняковская, Роль Clostridium Pasteurianum как фактора, повышающего эффективность бактеризации семян азотобактером, «Микробнология», т. XVII, вып. 5, 1948.

5. Ю. М. Возняковская, А. С. Р ыжков а, Влияние смеси органических и минеральных удобрений на микрофлору почвы, Доклады ВАСХНИЛ, вып. 6, 1954.

6. Н. А. К ра с ил ьн и ков, Микроорганизмы и плодородие почвы, Изв, АН СССР, серия биологическая,, № $2,1954$.

7. В. Л. Ом елян ск и й, Избранные труды, т. 1, 1953.

8. А. В. Р ыб алкина, К сравнительной характеристике некоторых почвенных микроорганизмов, Труды Почвенного института им. Докучаева, т. XXXVII, 1951 .

9. М. В. Фе доров, Биологическая фиксация азота атмосферы, Сельхозгиз, 1952.

10. М. 3. Шкля р, Взаимное влияние азотобактера и Clostridium Pasteurianum в смешанной культуре, Труды Всесоюзного научно-исследовательского института сельскохозяйственной микробиологии, т. ХІ, вып. 2, 1951.

11. D. Rosenblum and P. W. Wilson, Molecular Hydrogen and Nitrogen Fixation by Clostridium, Journal of Bacteriology, Vol. 59, No 1, p. 83, 1950. 